\title{
Effect of rice straw in the diet for growing goats on site and extent of digestion and $\mathrm{N}$ balance*
}

\author{
X.G. Zhao ${ }^{1,2}$, H.L. Jiang ${ }^{1,2}$, Z.H. Sun ${ }^{1}$, S.X. Tang ${ }^{1}$, C.S. Zhou ${ }^{1,2}$, \\ Z.H. Cong ${ }^{1,2}$, G.O. Tayo ${ }^{1,3}$ and Z.L. Tan ${ }^{1,4}$ \\ ${ }^{1}$ Key Laboratory of Agricultural Ecological Engineering, Institute of Subtropical Agriculture, \\ The Chinese Academy of Sciences \\ Hunan 410125, P.R. China \\ ${ }^{2}$ Graduate University of the Chinese Academy of Sciences \\ Beijing 100039, P.R. China \\ ${ }^{3}$ Department of Agriculture, Babcock University \\ Ilishan-Remo, Nigeria
}

(Received 8 November 2006; revised version 9 April 2007; accepted 6 September 2007)

\begin{abstract}
Effect of reducing dietary rice straw on $\mathrm{N}$ balance, site and extent of digestion, and efficiency of microbial protein synthesis were evaluated in this trial. Four Liuyang black goats (average body weight $19.3 \pm 2.1 \mathrm{~kg}$ ), fitted with the ruminal, proximal duodenal and terminal ileal cannulas were used in a $4 \times 4$ Latin square design. Goats were assigned to four dietary treatments designed by increasing maize grain inclusion at the expense of rice straw: $1.40 \%$ forage (20\% maize stover and $20 \%$ rice straw, HR); 2 . $35 \%$ forage ( $20 \%$ maize stover and $15 \%$ rice straw, MR1); $3.30 \%$ forage ( $20 \%$ maize stover and $10 \%$ rice straw, MR2) and $4.25 \%$ forage (20\% maize stover and 5\% rice straw, LR). Experimental diets were similar in chemical composition except for dietary NDF and metabolizable energy content. The amount of diet offered to each goat was restricted to $85 \%$ of its ad libitum intake to maintain no orts during the whole experimental period. There were no differences in DMI as a result of restricting intake. Totaltract digestibility of $\mathrm{OM}(\mathrm{P}<0.01), \mathrm{N}(\mathrm{P}<0.01)$ and NDF $(\mathrm{P}<0.05)$ increased with reducing dietary rice straw. Retained N increased from $12.04 \%$ for HR to $21.62 \%$ for $\mathrm{LR}(\mathrm{P}<0.01)$. Efficiency of microbial protein synthesis was not affected by dietary rice straw $(\mathrm{P}>0.05)$. When expressed as a percentage of $\mathrm{N}$ intake, ruminal $\mathrm{N}$ disappearance was not affected $(\mathrm{P}>0.05)$ by treatments. The true ruminal $\mathrm{OM}$, apparent ruminal $\mathrm{OM}$ and ruminal NDF disappearance increased $(\mathrm{P}<0.01)$ with reducing dietary rice straw. There were no differences $(\mathrm{P}>0.05)$ in small intestinal digestibility of $\mathrm{OM}$ and $\mathrm{N}$ among the treatments.
\end{abstract}

\footnotetext{
* Supported by the Project "Knowledge Innovation, Kscx2-Yw-N-022", Natural Science

Foundation of Hunan Province (05JJ10004) and National Science Foundation of China, No. 3057352

${ }^{4}$ Corresponding author: e-mail: zlatan@isa.ac.cn
} 
Our data indicated that reducing dietary rice straw from 40 to $25 \%$ could improve utilization of nutrients by growing goats.

KEY WORDS: rice straw, digestibility, efficiency of microbial protein synthesis, $\mathrm{N}$ balance, goat

\section{INTRODUCTION}

In growing ruminants, rations that contain high grain levels are fed in order to meet energy requirements for weight gain. However, reducing dietary rice straw may generally increase the incidence of digestive disturbances related with rumen acidosis (Krause and Oetzel, 2006). Grant (1994) found that in cattle, digestibility of nutrients decreased as the dietary rice straw reduced, and this was related to a decrease in rumen $\mathrm{pH}$, and an increased lag time of fibre digestion. However, Fimbres et al. (2002b) reported that reducing dietary rice straw increased nutrients digestion and chewing activity in lambs.

While there is a comprehensive understanding of the effects of dietary forage on the digestibility of nutrients in cattle and sheep, very little research has been conducted to test the role of forage in digestion and metabolism in goats. Goats as ruminants also require adequate dietary fibre from forage for normal rumen function, which is associated with rumination to maintain adequate salivation and optimal $\mathrm{pH}$ for digestion. However, goats differ in feeding behaviour, level of intake, diet selection, taste discrimination and rate of eating from sheep and cattle (Reid et al., 1990). Because of these differences the knowledge obtained from other ruminant species may not always be extrapolated to goats.

In fact, dietary rice straw for goats has not been defined by the current nutrition guidelines (Lu et al., 2005). However, dietary rice straw is vital in the digestion of nutrients mediated through mastication and microbial fermentation in the rumen. This study aimed to evaluate the effect of dietary rice straw for growing goats on site and extent of digestion and $\mathrm{N}$ balance.

\section{MATERIAL AND METHODS}

\section{Experimental animals and diets}

A $4 \times 4$ Latin square experiment was conducted with four 6-month old Liuyang black goats (a local breed in China), with an initial body weight of $19.3 \pm 2.1$ $\mathrm{kg}$, fitted with the ruminal, proximal duodenal and terminal ileal cannulae. The surgery was followed by a recovery period of 30 days during which the wound was cleaned with potassium iodide and then covered with an anti-inflammatory agent. Each goat received penicillin K (80,000 IU) twice daily for 7 days, close attention 
was also paid to possible displacement or plugging of fistulae. Goats were housed in a temperature controlled room $\left(20^{\circ} \mathrm{C}\right)$ in individual stainless metabolism cages $(41 \times 127 \mathrm{~cm})$. All goats had free access to fresh water. The forage component of diets was fed once daily at 07.30 and the concentrate twice daily in two equal amounts at 07.30 and $17.30 \mathrm{~h}$. Forage and concentrate offered and refused were weighed daily for $7 \mathrm{~d}$ before the commencement of the experiment to measure the voluntary feed intake.

During the whole experimental period, goats were randomly allotted to four dietary treatments with similar crude protein content. The dietary rice straw decreased with the replacement of rice straw with ground maize as follows: 1 . $40 \%$ forage (20\% maize stover and $20 \%$ rice straw, HR); $2.35 \%$ forage $(20 \%$ maize stover and $15 \%$ rice straw, MR1); $3.30 \%$ forage (20\% maize stover and $10 \%$ rice straw, MR2) and $4.25 \%$ forage (20\% maize stover and $5 \%$ rice straw, LR). Ingredients and composition of diets are shown in Table 1 . The amount of diets offered to each goat was restricted to $85 \%$ of its ad libitum intake to maintain no orts.

Table 1. Ingredients and chemical composition of the experimental diets

\begin{tabular}{lcccc}
\hline \multirow{2}{*}{ Item } & \multicolumn{4}{c}{ Treatments } \\
\cline { 2 - 5 } Ingredient, \% of DM & HR & MR1 & MR2 & LR \\
maize stover & 20 & 20 & 20 & 20 \\
rice straw & 20 & 15 & 10 & 5 \\
ground maize & 24.05 & 29.75 & 35.35 & 41.05 \\
soyabean meal & 9.3 & 8.6 & 8.0 & 7.3 \\
wheat bran & 19.2 & 19.2 & 19.2 & 19.2 \\
maize starch & 0.1 & 0.1 & 0.1 & 0.1 \\
fish meal & 4.6 & 4.6 & 4.6 & 4.6 \\
urea & 0.17 & 0.17 & 0.17 & 0.17 \\
sodium chloride & 0.5 & 0.5 & 0.5 & 0.5 \\
calcium carbonate & 0.58 & 0.58 & 0.58 & 0.58 \\
Premix & 1.5 & 1.5 & 1.5 & 1.5 \\
& & & & \\
Analysed dietary nutrient content, \%DM & & & & \\
DM & 86.4 & 86.2 & 86.0 & 85.7 \\
OM & 93.1 & 91.6 & 92.6 & 92.5 \\
CP & 14.9 & 14.9 & 14.9 & 14.9 \\
NDF & 39.7 & 36.7 & 34.2 & 31.5 \\
NDF from forage & 26.6 & 23.2 & 19.9 & 16.6 \\
ADF & 23.6 & 21.5 & 19.4 & 17.3 \\
Ca & 0.67 & 0.65 & 0.64 & 0.63 \\
P & 0.39 & 0.39 & 0.39 & 0.39 \\
Calculated ME, Mcal/Kg DM & 2.21 & 2.29 & 2.37 & 2.44 \\
\hline
\end{tabular}

Premix contained per kg, g: $\mathrm{MgSO}_{4} \cdot \mathrm{H}_{2} \mathrm{O} 119, \mathrm{FeSO}_{4} \cdot 7 \mathrm{H}_{2} \mathrm{O} 2.5, \mathrm{CuSO}_{4} \cdot 5 \mathrm{H}_{2} \mathrm{O} 0.8, \mathrm{MnSO}_{4} \cdot \mathrm{H}_{2} \mathrm{O} 3$, $\mathrm{ZnSO}_{4} \cdot \mathrm{H}_{2} \mathrm{O} 5 ; \mathrm{mg}: \mathrm{Na}_{2} \mathrm{SeO}_{3} 10, \mathrm{KI} 40, \mathrm{CoCl}_{2} \cdot 6 \mathrm{H}_{2} \mathrm{O} 30$ : IU: vit. A 95,000, vit. D 17,500, vit. E 18,000 HR - $40 \%$ forage; MR 1 - $35 \%$ forage; MR2 - 20\% forage; LR - $15 \%$ forage; ME - metabolizable energy, calculated by the data of Zhang and Zhang (1998) 


\section{Sampling and analysis}

Each experimental period lasted for $26 \mathrm{~d}$ comprising of $12 \mathrm{~d}$ of diet adaptation and $14 \mathrm{~d}$ of sampling with at least $3 \mathrm{~d}$ between periods. The amount of feed offered was weighed daily for each goat during the sampling period. Samples of dietary ingredients $(0.5 \mathrm{~kg})$ were collected daily, composited into one sample per goat during d 13 to d 25 , and dried at $65^{\circ} \mathrm{C}$ for $48 \mathrm{~h}$. Faeces and urine from all goats were daily collected quantitatively during the first 4 sampling days to determine $\mathrm{N}$ balance. Total faecal output was weighed daily, and a $10 \%$ subsample was collected and frozen. Urine was collected in a sealed-top container using a funnel and drainage hose. Each urine collection container contained $50 \mathrm{ml}$ of $6 \mathrm{M}$ $\mathrm{HCl}$ to stabilize urinary ammonia by bringing the $\mathrm{pH}$ below 3.5. Urine was quantified daily, and a $10 \%$ subsample was collected and frozen $\left(-20^{\circ} \mathrm{C}\right)$. Urine and faecal samples were composited by animal within period, so that there were one urine and one faecal sample for each goat in each period. On d 17, $50 \mathrm{ml}$ ruminal samples were taken from each goat at 07.00, 09.00, 11.00, 13.00, 16.00, $19.00,22.00 \mathrm{~h}$ and at $01.00,04.00$ on $\mathrm{d} 18$ through the ruminal cannula. Ruminal samples were composited by goat within period to separate ruminal bacteria pellet. Bacteria samples were lyophilized using the freeze-drying machine (GLZY-0.5B, Shanghai Pudong Freeze Dryer Equipment Co. Ltd., China).

Chromic oxide was used as a marker to estimate nutrient digestibility in the forestomach and small intestine. One $\mathrm{g}$ of chromic oxide was dosed through the rumen cannula at $06.00,12.00,18.00$ and $24.00 \mathrm{~h}$ (total of $4 \mathrm{~g}$ of $\mathrm{Cr}_{2} \mathrm{O}_{3} / \mathrm{d}$ ) from day 19 to 26 with the primal dose of $2 \mathrm{~g}$ at 06.00 on d 19 . Approximately $30 \mathrm{ml}$ duodenal and ileal contents were collected at 06.00, 12.00, 18.00 and 24.00 on d 24 , at $04.00,10.00,16.00$, and 22.00 on d 25 and at $02.00,08.00,14.00$ and 20.00 on d 26, respectively. After all collection, duodenal and ileal samples were composited by goat for each period and lyophilized.

\section{Analytical procedures}

All dried samples of maize stover, concentrate, faeces, duodenal digesta and ileal digesta were ground through a mill (1 mm screen; DF-2, Changsha Instrument Factory, China). DM, OM, NDF N and ADF of samples were analysed according to AOAC (2002).

Samples of about $30 \mathrm{ml}$ duodenal and ileal digesta were prepared as described by Williams et al. (1962) for analysis of Cr using atomic absorption spectroscopy (Model 932AA, GBC Scientific Equipment Pty Ltd., Australia). Duodenal and ileal $\mathrm{Cr}$ concentration was used in conjunction with nutrient concentration to determine duodenal and ileal nutrient flow (Tan et al., 2002). The ruminal bacteria were separated from protozoa and feed particles in ruminal fluid according to 
the method of Reed et al. (2004). The isolated bacteria pellet were lyophilized, ground with a mortar and pestle, and analysed for DM, OM, N (AOAC, 2002). The ruminal bacteria pellets and about $150 \mathrm{ml}$ lyophilized duodenal digesta were analysed for concentration of diaminopimelic acid (DAPA) as described by Olubobokun et al. (1988). The ratio of DAPA to bacteria N, and bacteria OM were determined for ruminal microbial pellets. The duodenal flows of microbial $\mathrm{N}$ and $\mathrm{OM}$ were calculated by multiplying the ratios of DAPA: bacteria $\mathrm{N}$ and DAPA: bacteria OM by the duodenal DAPA concentration, respectively. About $20 \mathrm{ml}$ lyophilized duodenal digesta samples were hydrated for $20 \mathrm{~min}$ to extract ammonia $\mathrm{N}$ retained in samples, then ammonia $\mathrm{N}$ concentration was analysed according to the method of Broderick and Kang (1980) to estimate ammonia N flow at the duodenum.

\section{Statistical analysis}

All data were analysed as a $4 \times 4$ Latin square design using the GLM procedure of SAS (1996). The model used was:

$$
\mathrm{Y}_{\mathrm{ijk} k}=\mu_{\mathrm{i}}+\mathrm{G}_{\mathrm{i}}+\mathrm{P}_{\mathrm{j}}+\mathrm{T}_{\mathrm{k}}+\mathrm{e}_{\mathrm{ijk} \mathrm{k}}
$$

where: $\mu$ is the overall mean, $G_{i}$ is the effect of goat ( $i=1$ to 4 ), $P_{j}$ is effect of period ( $\mathrm{j}=1$ to 4$), \mathrm{T}_{\mathrm{k}}$ is fixed effect of treatment ( $\mathrm{k}=1$ to 4 ), and $\mathrm{e}_{\mathrm{ijkl}}$ is residual. Where the treatment effect was significant, differences among means were tested with Duncan's multiple range tests. Statistical significances were considered to exist if $\mathrm{P}<0.05$.

\section{RESULTS}

Daily OM and NDF intake and digestibility at different sites are given in Table 2. There were no differences in OM intake and duodenal microbial OM flow between the treatments. Faecal OM excretion $(\mathrm{P}<0.01)$ and duodenal OM flow $(\mathrm{P}<0.01)$ decreased as dietary rice straw reduced. Apparent ruminal $\mathrm{OM}$ disappearance, true ruminal $\mathrm{OM}$ disappearance and apparent total-tract $\mathrm{OM}$ digestibility increased $(\mathrm{P}<0.01)$ as the dietary rice straw reduced. Apparent intestinal OM digestibility was not affected by treatments. NDF intake decreased $(\mathrm{P}<0.01)$ as dietary rice straw reduced. There were differences in faecal NDF excretion and duodenal NDF flow $(\mathrm{P}<0.01)$ among four treatments. Ruminal disappearance and total-tract digestibility of NDF increased $(\mathrm{P}<0.05)$ with reducing dietary rice straws.

Effect of dietary rice straw on $\mathrm{N}$ balance is shown in Table 3. Dietary rice straw had no effect on $\mathrm{N}$ intake and urine $\mathrm{N}$ excretion $(\mathrm{P}>0.05)$. Faecal $\mathrm{N}$ decreased with the reduction in dietary forage contents $(\mathrm{P}<0.05)$. $\mathrm{N}$ balance and retention increased $(\mathrm{P}<0.05)$ as dietary rice straw reduced. 
Table 2. Effect of dietary forage level on organic matter and neutral detergent fibre digestion in growing goats

\begin{tabular}{|c|c|c|c|c|c|}
\hline \multirow{2}{*}{ Item } & \multicolumn{4}{|c|}{ Treatments $^{1}$} & \multirow{2}{*}{ SEM } \\
\hline & HR & MR1 & MR2 & LR & \\
\hline \multicolumn{6}{|l|}{ Organic matter } \\
\hline intake, $\mathrm{g} / \mathrm{d}$ & 469.0 & 468.8 & 463.7 & 470.8 & 0.1 \\
\hline duodenal flow, $\mathrm{g} / \mathrm{d}$ & $228.6^{\mathrm{a}}$ & $217.9^{\mathrm{b}}$ & $215.2^{\mathrm{b}}$ & $203.9^{c}$ & 2.7 \\
\hline duodenal microbial OM flow, $\mathrm{g} / \mathrm{d}$ & 40.7 & 40.4 & 40.6 & 41.2 & 0.8 \\
\hline \multicolumn{6}{|l|}{ ruminal disappearance } \\
\hline apparent, $\mathrm{g} / \mathrm{d}$ & $240.6^{c}$ & $251.1^{\mathrm{b}}$ & $253.4^{\mathrm{b}}$ & $265.0^{\mathrm{a}}$ & 2.7 \\
\hline true, $\mathrm{g} / \mathrm{d}$ & $281.3^{\mathrm{c}}$ & $291.5^{\mathrm{b}}$ & $294.1^{\mathrm{b}}$ & $306.3^{\mathrm{a}}$ & 2.9 \\
\hline apparent, $\%$ intake & $51.2^{\mathrm{c}}$ & $53.5^{\mathrm{b}}$ & $54.0^{\mathrm{b}}$ & $56.5^{\mathrm{a}}$ & 0.6 \\
\hline true, $\%$ intake & $59.9^{\mathrm{c}}$ & $62.1^{\mathrm{bc}}$ & $62.7^{b}$ & $65.3^{\mathrm{a}}$ & 0.6 \\
\hline ileum flow, g/d & $156.9^{\mathrm{a}}$ & $150.6^{\mathrm{ab}}$ & $142.7^{\mathrm{ab}}$ & $138.1^{\mathrm{b}}$ & 4.4 \\
\hline \multicolumn{6}{|l|}{ apparent intestinal digestibility } \\
\hline$\%$ intake & 14.1 & 13.1 & 15.2 & 13.6 & 2.2 \\
\hline$\%$ duodenal OM flow & 29.1 & 28.7 & 32.7 & 30.7 & 3.8 \\
\hline faecal output, $\mathrm{g} / \mathrm{d}$ & $144.4^{\mathrm{a}}$ & $142.6^{\mathrm{ab}}$ & $132.8^{\mathrm{bc}}$ & $123.7^{\mathrm{c}}$ & 3.1 \\
\hline total-tract digestibility, $\%$ intake & $69.3^{\mathrm{c}}$ & $69.6^{\mathrm{bc}}$ & $71.6^{\mathrm{ab}}$ & $73.7^{\mathrm{a}}$ & 0.7 \\
\hline \multicolumn{6}{|l|}{ Neutral detergent fibre } \\
\hline intake $\mathrm{g} / \mathrm{d}$ & $201.3^{\mathrm{a}}$ & $187.1^{\mathrm{b}}$ & $173.3^{\mathrm{c}}$ & $159.3^{\mathrm{d}}$ & 0.2 \\
\hline duodenal flow, $\mathrm{g} / \mathrm{d}$ & $128.5^{\mathrm{a}}$ & $114.1^{\mathrm{b}}$ & $103.6^{\mathrm{c}}$ & $90.2^{\mathrm{d}}$ & 1.3 \\
\hline ruminal disappearance, $\%$ intake & $36.2^{\mathrm{c}}$ & $39.0^{\mathrm{b}}$ & $40.2^{\mathrm{b}}$ & $43.3^{\mathrm{a}}$ & 0.7 \\
\hline faecal output, $g / d$ & $128.5^{\mathrm{a}}$ & $114.1^{\mathrm{b}}$ & $103.6^{\mathrm{c}}$ & $90.2^{\mathrm{d}}$ & 1.3 \\
\hline total-tract digestibility, $\%$ intake & $44.0^{\mathrm{a}}$ & $47.9^{\mathrm{ab}}$ & $48.1^{\mathrm{ab}}$ & $50.9^{\mathrm{b}}$ & 1.4 \\
\hline
\end{tabular}

a,b,c,d means with different superscripts in the same row differ $(\mathrm{P}<0.05)$

${ }^{1}$ see Table 1

SEM - the pooled standard error of means; true ruminal OM disappearance - corrected for OM of bacterial origin

Table 3. Effect of dietary forage level on nitrogen balance in growing goats

\begin{tabular}{lccccc}
\hline \multirow{2}{*}{ Item } & \multicolumn{4}{c}{ Treatments $^{1}$} & \multirow{2}{*}{ SEM } \\
\cline { 2 - 5 } & HR & MR1 & MR2 & LR & \\
\hline N intake, g/d & 12.11 & 12.16 & 12.14 & 12.15 & 0.02 \\
Faecal N, g/d & $2.37^{\mathrm{a}}$ & $2.07^{\mathrm{ab}}$ & $1.79^{\mathrm{b}}$ & $1.74^{\mathrm{b}}$ & 0.10 \\
Urine N, g/d & 8.28 & 8.23 & 8.10 & 7.72 & 0.21 \\
Apparent absorbed N, g/d & $9.74^{\mathrm{b}}$ & $10.02^{\mathrm{ab}}$ & $10.31^{\mathrm{a}}$ & $10.33^{\mathrm{a}}$ & 0.10 \\
Apparent absorbed N, \% intake & $80.44^{\mathrm{b}}$ & $82.85^{\mathrm{ab}}$ & $85.22^{\mathrm{a}}$ & $85.55^{\mathrm{a}}$ & 0.20 \\
Retained N, g/d & $1.46^{\mathrm{c}}$ & $1.79^{\mathrm{bc}}$ & $2.21^{\mathrm{ab}}$ & $2.61^{\mathrm{a}}$ & 0.14 \\
Retained N, \% intake & $12.04^{\mathrm{c}}$ & $14.77^{\mathrm{bc}}$ & $18.28^{\mathrm{ab}}$ & $21.62^{\mathrm{a}}$ & 1.16 \\
\hline
\end{tabular}

a,b,c,d means with different superscripts in the same row differ $(\mathrm{P}<0.05)$

${ }^{1}$ see Table 1

SEM - the pooled standard error of means

The effect of dietary rice straw on $\mathrm{N}$ digestibility at different sites and efficiency of microbial protein synthesis are presented in Table 4. Duodenal flows of total $\mathrm{N}$, bacterial $\mathrm{N}$ and ammonia $\mathrm{N}$ were not affected $(\mathrm{P}>0.05)$ by 
reducing dietary rice straw. However, non-bacterial $\mathrm{N}$ flow to the duodenum was higher $(\mathrm{P}<0.05)$ for HR than for other treatments. The ratio of $\mathrm{N}$ to DAPA and OM to DAPA were not affected by treatments $(\mathrm{P}>0.05)$ in the isolated bacteria. Efficiency of microbial protein synthesis ( $\mathrm{g}$ microbial N/100 g apparent ruminal fermentable OM, or $\mathrm{g}$ microbial $\mathrm{N} / 100 \mathrm{~g}$ true ruminal fermentable $\mathrm{OM}$ ) was not

Table 4. Effect of different dietary forage level on $\mathrm{N}$ digestion and efficiency of microbial protein synthesis in growing goats

\begin{tabular}{lccccc}
\hline \multirow{2}{*}{ Item } & \multicolumn{4}{c}{ Treatments $^{1}$} & \multirow{2}{*}{ SEM } \\
\cline { 2 - 5 } & HR & MR1 & MR2 & LR & \\
\hline N intake, g/d & 12.11 & 12.16 & 12.14 & 12.15 & 0.02 \\
Duodenal N flow, g/d & & & & & \\
$\quad$ total N, g/d & 9.92 & 9.38 & 9.23 & 9.59 & 0.24 \\
$\quad$ bacterial N, g/d & 5.55 & 6.66 & 6.56 & 6.42 & 0.36 \\
$\quad$ NBN, g/d & $4.37^{\mathrm{a}}$ & $2.71^{\mathrm{b}}$ & $2.67^{\mathrm{b}}$ & $2.82^{\mathrm{b}}$ & 0.44 \\
ammonia N, g/d & 0.54 & 0.50 & 0.59 & 0.51 & 0.04 \\
& & & & & \\
Isolated bacteria & & & & & \\
$\quad$ N:DAPA & 0.019 & 0.019 & 0.019 & 0.018 & 0.001 \\
OM:DAPA & 6.33 & 6.4 & 6.32 & 6.47 & 0.16
\end{tabular}

Efficiency of microbial protein synthesis

$\begin{array}{llllll}\text { g N/100 g OMDA } & 2.3 & 2.7 & 2.6 & 2.4 & 0.1 \\ \text { g N/100 g OMDT } & 2.0 & 2.3 & 2.2 & 2.1 & 0.1\end{array}$

Ruminal $N$ disappearance apparent

\begin{tabular}{|c|c|c|c|c|c|}
\hline $\mathrm{g} / \mathrm{d}$ & 2.2 & 2.7 & 2.9 & 2.8 & 0.3 \\
\hline$\%$ intake & 17.9 & 22.3 & 23.4 & 23.0 & 2.0 \\
\hline \multicolumn{6}{|l|}{ true } \\
\hline$g / d$ & $7.7^{\mathrm{b}}$ & $9.4^{\mathrm{a}}$ & $9.4^{\mathrm{a}}$ & $9.3^{\mathrm{ab}}$ & 0.4 \\
\hline$\%$ intake & $63.7^{\mathrm{b}}$ & $77.3^{\mathrm{a}}$ & $77.7^{\mathrm{a}}$ & $76.2^{\mathrm{a}}$ & 3.5 \\
\hline
\end{tabular}

Intestinal digestibility of $N$

\begin{tabular}{llllll} 
\% intake & 61.4 & 57.1 & 55.7 & 59.4 & 2.4 \\
\% duodenal total N flow & 74.9 & 73.4 & 72.3 & 76.6 & 1.3 \\
\hline
\end{tabular}

a,b,c,d means with different superscripts in the same row differ $(\mathrm{P}<0.05)$

${ }^{1}$ see Table 1

SEM - the pooled standard error of means; true ruminal $\mathrm{N}$ disappearance - corrected for $\mathrm{N}$ of bacterial origin; NBN - non-bacterial N

OMDA - apparent ruminal OM disappearance; OMDT - true ruminal OM disappearance

affected $(\mathrm{P}>0.05)$ by reducing dietary rice straws. There were no differences $(\mathrm{P}>0.05)$ in apparent ruminal $\mathrm{N}$ disappearance as well as intestinal $\mathrm{N}$ digestibility among four treatments. However, true ruminal $\mathrm{N}$ disappearance was lower $(\mathrm{P}<0.05)$ in HR diet when compared with other dietary treatments. 


\section{DISCUSSION}

In this study, ground maize replaced by rice straw at 5, 10, 15 and $20 \%$ levels to give MR1, MR2, LR and HR treatments, respectively. The ruminal OM and NDF disappearance, apparent total-tract OM, N and NDF digestibility increased as dietary rice straw level reduced. These results agree with the findings of Fimbres et al. (2002a) who reported a considerable increase in apparent total tract $\mathrm{OM}$ and NDF digestibility as a result of decreasing dietary klein grass (Panicum coloratum L.) hay and increasing sorghum grain in lambs. In this regard, increase in OM and fibre digestion resulting from supplementation of readily fermentable carbohydrates is probably a consequence of preferential utilization by ruminal microorganisms (Arroquy et al., 2004). However, Gorocica-Buenfil and Loerch (2005), reported that dietary rice straw did not influence apparent total-tract OM and NDF digestibility in steers when $13 \%$ maize silage was replaced by maize. Similarly, other previous studies (Zinn et al., 1994; Calderon-Cortes and Zinn, 1996) have demonstrated that replacing $8 \%$ Sudan grass with maize did not affect the ruminal disappearance of OM and NDF in steers. These results indicate that the effect of dietary rice straw on OM and NDF digestion in forestomach and post-digestive tract probably depends upon animal species. Gonzalez-Lopez et al. (1990) suggested that rumen microorganisms are not easily affected by dietary nutritional factors in goats. However, in our study the increase in dietary readily fermentable carbohydrate not only enhanced the ruminal disappearance but also total-tract digestibility of OM and NDF in goats within the present range of dietary rice straw.

$\mathrm{N}$ balance data indicated that $\mathrm{N}$ utilization efficiency increased with the decrease of dietary rice straw in our experiment. Because all animals were cannulated at the rumen, duodenum and ileum, their growth performance might be influenced by the surgery. Therefore, the animals were not weighed in a manner that would provide data to evaluate protein weight gain based on $\mathrm{N}$ retention. The significant improvement of $\mathrm{N}$ retention and digestibility was consistent with other previous trials (Calderon-Cortes and Zinn, 1996; Fimbres et al., 2002b). Fimbres et al. (2002b) reported that $\mathrm{N}$ retained was positively related to dietary energy density and inversely related to dietary hay level. Accordingly, increase of $\mathrm{N}$ retention and digestion, which resulted from the partial replacement of rice straw with maize, is due to a higher biological availability of energy and protein from maize than from rice straw.

Dietary rice straw level did not affect flows of total $\mathrm{N}$, microbial $\mathrm{N}$ and $\mathrm{NH}_{3}-\mathrm{N}$ to the duodenum except for non-bacterial $\mathrm{N}$, but true ruminal $\mathrm{N}$ digestion increased with reducing dietary rice straw levels in this study. Calderon-Cortes and Zinn (1996) also demonstrated that the duodenal flows of total $\mathrm{N}, \mathrm{NH}_{3}-\mathrm{N}$ and microbial $\mathrm{N}$ were not affected by the replacement of Sudan grass from 16 to $8 \%$ with steam- 
flaked maize. Increase in true ruminal $\mathrm{N}$ digestion and decrease in non-bacteria $\mathrm{N}$ flow to the duodenum with reducing dietary rice straw levels is probably due to lower degradability of rice straw than maize in the rumen. Moreover, the present results indicated that efficiency of microbial protein synthesis was not affected by treatment and that ruminal microbial protein provided majority of protein supplied to the small intestine of goats. This is consistent with the previous findings of Bach et al. (2005). Rapidly fermentable carbohydrates are mainly supplied by grain based concentrates for goats (Tothi et al., 2003), and adenosine triphosphate (ATP) derived from carbohydrate fermentation can improve the ruminal microbial growth. Accordingly, replacing dietary forage with grain is possibly beneficial for ruminal microbial protein synthesis in goat. This seemed to be inconsistent with our results. However, Calderon-Cortes and Zinn (1996) also found that dietary Sudan grass level did not affect efficiency of microbial protein synthesis when replacing 8\% Sudan grass with steam-flaked maize. Soto-Navarro et al. (2006), assumed that efficiency of ruminal microbial protein synthesis could be kept relatively stable when the supply of easily fermentable carbohydrate was adequate to satisfy the maximal microbial growth in the rumen. The results of our study implied that the easily fermentable carbohydrates from each experimental diet were adequate to meet the requirement of ruminal microbial protein synthesis.

\section{CONCLUSIONS}

In growing goats fed at restricted intakes ( $85 \%$ of ad libitum intake), reducing dietary rice straw from 40 to $25 \%$ improved OM and NDF digestion in the forestomach. Total tract $\mathrm{OM}$ digestibility and retained $\mathrm{N}$ also increased with the reduction in dietary rice straws. The change in dietary rice straw levels (from 20 to $5 \%$ ) did not affect the ruminal $\mathrm{N}$ disappearance, small intestinal $\mathrm{N}$ digestibility and efficiency of microbial protein synthesis.

\section{REFERENCES}

AOAC, 2002. Association of Official Analytical Chemists, Official Methods of Analysis. $16^{\text {th }}$ Edition. Washington, DC

Arroquy J.I., Cochran R.C., Villarreal M., Wickersham T.A., Llewellyn D.A., Titgemeyer E.C., Nagaraja T.G., Johnson D.E., Gnad D., 2004. Effect of level of rumen-degradable protein and type of supplemental non-fibre carbohydrate on intake and digestion of low-quality grass hay by beef cattle. Anim. Feed Sci. Tech. 115, 83-99

Bach A., Calsamiglia S., Stern M.D., 2005. Nitrogen metabolism in the rumen. J. Dairy Sci. 88, E9-E21

Broderick G.A., Kang J.H., 1980. Automated simultaneous determination of ammonia and total amino acids in ruminal fluid and in vitro media. J. Dairy Sci. 63, 64-75 
Calderon-Cortes J.F., Zinn R.A., 1996. Influence of dietary forage level and forage coarseness of grind on growth performance and digestive function in feedlot steers. J. Anim. Sci. 74, 23102316

Fimbres H., Hernandez-Vidal G., Picon-Rubio J.F., Kawas J.R., Lu C.D., 2002a. Productive performance and carcass characteristics of lambs fed finishing ration containing various forage levels. Small Ruminant Res. 43, 283-288

Fimbres H., Kawas J.R., Hernandez-Vidal G., Picon-Rubio J.F., Lu C.D., 2002b. Nutrient intake, digestibility, mastication and ruminal fermentation of lambs fed finishing ration with various forage levels. Small Ruminant Res. 43, 275-281

Gonzalez-Lopez J., Salmeron V., Ramos-Cormenzana A., Silva-Colomer J., Boza J., 1990. Influence of several feeds on bacteria in sheep and goat rumen liquor in vitro. Microbios 62, 75-81

Gorocica-Buenfil M.A., Loerch S.C., 2005. Effect of cattle age, forage level, and corn processing on diet digestibility and feedlot performance. J. Anim. Sci. 83, 705-714

Grant R.J., 1994. Influence of corn and sorghum starch in the in vitro kinetics of forage fiber digestion. J. Dairy Sci. 71, 1563-1569

Krause K.M., Oetzel G.R., 2006. Understanding and preventing subacute ruminal acidosis in dairy herds: A review. Anim. Feed Sci. Tech. 126, 215-236

Lu C.D., Kawas J.R., Mahgoub O.G., 2005. Fibre digestion and utilization in goats. Small Ruminant Res. 60, 45-52

Olubobokun J.A., Craig W.M., Nipper W.A., 1988. Characteristics of protozoal and bacterial fractions from microorganisms associated with ruminal fluid or particles. J. Anim. Sci. 66, 2701-2710

Reed J.J., Lardy G.P., Bauer M.L., Gilbery T.C., Caton J.S., 2004. Effect of field pea level on intake, digestion, microbial efficiency, ruminal fermentation, and in situ disappearance in beef steers fed growing diets. J. Anim. Sci. 82, 2123-2130

Reid R.L., Jung G.A., Cox-Ganser J.M., Rybeck B.F., Townsend E.C., 1990. Comparative utilization of warm- and cool-season forages by cattle, sheep and goats. J. Anim. Sci. 68, 2986-2994

SAS, 1996. SAS/STAT ${ }^{\circledR}$ User's Guide (Release 6.11). SAS Institute Inc. Cary, NC

Soto-Navarro S.A., Goetsch A.L., Sahlu T., Puchala R., 2006. Effects of level and source of supplemental protein in a concentrate-based diet on sites of digestion and small intestinal amino acid disappearance in Boer $\times$ Spanish wether goats. Small Ruminant Res. 65, 85-100

Tan Z.L., Lu D.X., Hu M., Niu W.Y., Han C.Y., Ren X.P., Na R., Lin S.L., 2002. Effect of dietary structural to nonstructural carbohydrate ratio on rumen degradability and digestibility of fiber fractions of wheat straw in sheep. Asian-Austr. J. Anim. Sci. 15, 1591-1598

Tothi R., Lund P., Weisbjerg M.R., Hvelplund T., 2003. Effect of expander processing on fractional rate of maize and barley starch degradation in the rumen of dairy cows estimated using rumen evacuation and in situ techniques. Anim. Feed Sci. Tech. 104, 71-94

Williams C.H., David D. J., Lismaa O., 1962. The determination of chromic oxide in faeces samples by atomic absorption spectrophotometry. J. Agr. Sci. 59, 381-385

Zhang H.F., Zhang Z.Y., 1998. Animal Nutrition Parameters and Feeding Standard (in Chinese). China Agriculture Press, Beijing (China), pp. 22-92

Zinn R.A., Plascencia A., Barajas R., 1994. Interaction of forage level and monensin in diets for feedlot cattle on growth performance and digestive function. J. Anim. Sci. 72, 2209-2215 